\title{
Criminal Law Protection Against Illegal Investment Entities in Indonesia
}

\author{
Edi Ribut Harwanto ${ }^{*}$ \\ 1.Head of the Laboratory of Law Faculty, Muhamadiyah Metro University \\ Advocate-Lecturer in Economic Criminal and Intellectual Property Rights at the Law Faculty of Muhammadiyah \\ Metro University
}

International Seminar on Foreign Investment Law in Indonesia-Muhammadiyah University Metro-28 October 2021

\begin{abstract}
The Investment Alert Task Force re-released the latest list of fraudulent investments in September 2020. At least, there were 99 illegal foreign and domestic investments that were included in the list. A total of 99 illegal investments are suspected of carrying out business activities without permission from the competent authority. These entities are considered to have the potential to harm the public because they commit fraud by offering very high and unreasonable returns. The formulation of the problem raised in this study is about the rise of illegal domestic investment crimes that duplicate business activities on behalf of officially licensed entities in Indonesia. In this research, the paradigm used is post-positivism paradigm. The post-positivism paradigm wants to prove that everything is based on reality that can be built based on experience, observation, researchers are neutral towards the object of research, even though the researcher holding this paradigm remains neutral towards the object of research, he wants to examine what actually happened from the things that happened. as if it was certain. The results of the study describe the modus operandi of domestic investment and foreign investment regulations based on Law Number 25 of 2007 concerning Investment and the reformulation of some clauses through the omnibus law of the Job Creation Act No. 11 of 2020. Rearrangement of investment regulations is expected to provide legal certainty from the perspective of regulation and legal protection from the perspective of law enforcement. In conclusion, the Financial Services Authority Investment Alert Task Force is needed, which is a combination of various law enforcement teams, must closely monitor the business activities of God's foreign capital investment in Indonesia and provide legal protection for investors who legally conduct business activities in Indonesia.
\end{abstract}

Keywords: Crime, Foreign Capital Investment, Omnibus Law, Investment Alert Task Force.

DOI: $10.7176 / \mathrm{JLPG} / 115-01$

Publication date: November $30^{\text {th }} 2021$

\section{INTRODUCTION}

One of the goals of establishing a state government is to promote the general welfare. The mandate, among others, has been described in Article 33 of the 1945 Constitution of the Republic of Indonesia and is a constitutional mandate that underlies the formation of all laws and regulations in the economic field. The constitution mandates that national economic development must be based on democratic principles that are able to create the realization of Indonesia's economic sovereignty. The linkage of economic development with people's economic actors was strengthened again by the Decree of the People's Consultative Assembly of the Republic of Indonesia Number XVI of 1998 concerning Economic Politics in the Context of Economic Democracy as a source of material law. Thus, the development of investment for micro, small, medium enterprises, and cooperatives is part of the basic investment policy. In this regard, investment must be part of the implementation of the national economy and be placed as an effort to increase national economic growth, create jobs, increase sustainable economic development, increase national technological capacity and capability, encourage people's economic development, and realize community welfare in a competitive economic system. The purpose of implementing investment can only be achieved if the supporting factors that hinder the investment climate can be overcome, among others through improved coordination between central and regional government agencies, the creation of an efficient bureaucracy, legal certainty in the investment sector, highly competitive economic costs, and climate conducive business sector in the field of employment and business security. With the improvement of these various supporting factors, it is hoped that the realization of investment will improve significantly.

In the development of legal principles in Indonesia, there are two laws that we know, namely, general criminal law, special criminal law in the Criminal Code, and special criminal law outside the Criminal Code. The Criminal Code is divided into three books, book I contains general provisions, book II contains crimes and book 
III deals with violations. ${ }^{1}$ Book II regulates all kinds of threats of criminal sanctions for crimes against state security, crimes against the dignity of the president and vice president, public order, fights, crimes endangering public safety, crimes against government power, false statements, decency, humiliation and others. In this book group II of the Criminal Code (KUHP), there are articles on fraud and embezzlement, 372-3377 of the Criminal Code, and articles of fraud 378-395 of the Criminal Code. From the development of special laws in the Criminal Code, special laws were made outside the Criminal Code, relating to fraud or embezzlement of investment funds which are regulated in Law Number 25 of 2007 concerning Investment. Because the general law is not able to answer the question of changes and new modes of crime, a special law is formed outside the Criminal Code to provide protection to the public. In legal developments, it turns out that Law No. 25 of 2007, is considered not to be able to answer the problem of foreign investment and there are still many new regulations that must be included in the text of the law, because the modus operandi of crime continues to change according to the times and is increasingly sophisticated by using modern facilities. modern technology. Then, in 2020, the government revamped the investment law with the omnibus law on job creation, UU No. 11 of 2020. This omnibus regulation is currently being implemented as a legal source for investment in Indonesia as a refreshing course.

One of the considerations for investors to invest in a country is legal certainty. Legal certainty includes certainty of regulation in laws and regulations and certainty of law enforcement. Omnibus Law is one of the concepts of managing several overlapping regulations by making a new regulation. The omnibus law is intended to organize regulations for the sake of certainty in the regulation of laws and regulations. This article discusses how to regulate investment regulations with the omnibus law and how the influence of regulatory arrangements on investment growth. To answer these problems, this research was conducted using normative legal research methods. In this normative legal research, primary legal materials and secondary legal materials are used. The results of the study indicate that the arrangement of investment regulations began with the promulgation of Law Number 25 of 2007 concerning Investment and arrangements through the omnibus law will be prepared in 2020 . The arrangement of investment regulations can provide legal certainty from a regulatory perspective, but does not necessarily provide legal certainty from a regulatory perspective. law enforcement perspective. The legal scientific approach can be interpreted as a method and program based on logical thinking or the construction of a certain orientation of thinking. The point of view of thinking about law can vary, so it is natural to often find mention of the term diverse legal scientific approaches. Among other things referred to as juridical, normative, dogmatic, legalistic, empirical, sociological, historical, comparative, philosophical approaches, policy oriented approaches, values approaches and approaches to national insight, global approaches, partial approaches and systemic and integral approaches. In the formation of investment legislation, now it is formed under another name omnibus law, which changes the combination of various kinds of legal regulations into one clump of law. Regarding law Investment growth is not only determined by regulatory arrangements, but is influenced by a conducive climate for investment, including security, ease of doing business, incentives, and economic conditions of a country. In the midst of structuring foreign and national capital investment regulations, there are many new modes of crime with entities as if businesses carried out in terms of foreign and national investment funds are carried out illegally by responsible parties.

Investment companies, which were previously detected by the Investment Alert Task Force of the Indonesian Financial Services Authority, revealed indications of crime in the investment sector. There is a list of 11 investment offers that were discontinued by SWI OJK. ${ }^{2}$ The companies whose operations were discontinued were, PT Overseas Commercial Future Company Duplication (PT Overseas Commercial Future Company Duplication was suspended and announced through a press release for conducting forex trading activities without permission), https://2021.co.id/application/application-wallet -ajaib/ (Illegal blog website in the name and duplication of activities of PT Takjub Teknologi Indonesia (Ajaib), Btrado (Offers for investment in trading robots without a permit), PT Nofal Invesment (Offers for investment without permission with falsification of permits from the Financial Services Authority), Cameto (Money Game ), WPP Group sharing/Sharing33.com, Sharing11.com, Sharing22.com (Money Game), SmartClicks.io/ PT AVA Sukses Sejahtera (Offers for investment in crypto assets without permission).SYW (Step In Your Wealth) (Money Game/ Unlicensed Crypto Assets in the name of SYW (Step In Your Wealth), BTC-FINANCIALTRADING (Offers of unauthorized crypto asset investment on behalf of BTC- FINANCIAL TRADING), UMI CRYPTO INVES TASI (Crypto asset investment offer with forgery permits from the Financial Services Authority), PT ZIV CRYPTO INDONESIA. As a developing country, Indonesia has a major problem in terms of capital. Capital is divided into two, namely domestic capital and foreign capital which is commonly referred to as debt. In its development, Indonesia prefers to use instant and fast ways to finance the economy by using foreign debt. The use of this foreign debt in the short and long term will affect the economy. Other indicators that are also related to capital are Foreign Investment (PMA) as a symbol of direct investment by multinational companies, Domestic Savings

\footnotetext{
${ }^{1}$ Sugandhi, Criminal Code With Explanation, National Business, Surabaya, 1980- pp. 390-396

Ferry Sandi, 'Jangan Salah Masuk, 11 Investasi Bodong Diblok OJK', CNBC Indonesia, https:/www.cnbcindonesia.com/market/20210724070700-17-263246/jangan-salah-masuk-11-investasi-bodong-diblok-ojk
}

2021 , 
as a symbol of independence of domestic capital and Debt Service Ratio as an indicator of Indonesia's ability to pay principal and foreign debt installments. The purpose of this study was to determine how the influence of the variables of Foreign Debt, Foreign Investment, Debt Service Ratio and Domestic Savings on Indonesia's economic growth in the period 2001-2011.

The Investment Alert Task Force of the Financial Services Authority of the Republic of Indonesia uncovered illegal investments. Of the 99 entities, 87 Illegal Futures or Forex Trading, 2 Illegal Direct Selling, 3 Illegal Cryptocurrency Investments, 3 Money Investments, and 4 others. The public needs to be careful of this illegal investment if there is an attractive legal and logical offer. Ask for the license of legal entities and their activities and see the rationality of the returns. (Head of the Investment Alert Task Force Togam L Tobing, Friday (3/7/2020)). The Investment Alert Task Force re-released the latest list of fraudulent investments in September 2020. At least, there were 32 illegal investments on the list. A total of 32 illegal investments are suspected of carrying out business activities without permission from the competent authority. These entities are considered to have the potential to harm the public because they commit fraud by offering very high and unreasonable returns. In addition, there are also many activities that duplicate the websites of licensed entities so that it seems as if the website is officially owned by a licensed entity. This was conveyed in an official report by the chairman of the Investment Alert Task Force Tongam L. Tobing in a press release held last Friday $(9 / 25 / 2020)$. One of the entities that was closed was the Alimama Indonesia application (almm.qdhtml.net) which recently became popular because it was suspected of committing fraud with the mode of raising funds to get shopping bonuses. In more detail, this is a list of 32 illegal entities handled by the Investment Alert Task Force. (Kompas.com-25/09/2020). ${ }^{1}$

1. The Integrated Wira Partner Producer Cooperative (My Win Trade). 2. Lucky Star/Sian-Sian Fortune 3. Bossque 4. International Digital Asset Entrepreneurs Association (PT Digital Asset Development Indonesia 5. Streammity/Cannis 6. Lucky Trade Community (LTC) 7. PT Recovery Investment Fund Online 8. Super-IBS (Super Sincere Social) 9. Amethyst.asia Also read: This is the Schedule and Method of Disbursing SBR008 Before Maturity 10. Play 100 Club/https://play100.club 11. SpeedMoney Smart/speedmoneysmart.com 12. Indonesian Alimama 13. Thumb Preneur Community (KJP) 14. Library/ Perpuskita.com 15. Money Bomber/ Uangbomber.com 16. Get Rich/ Be Rich.net 17. Flood Rizki Community (BRC)/ floodingrizki.com 18. Duitenterterus.com 19. Path of Dream/ pathofdream.com 20. Ghaniyyu100 Program/Ghaniyyu100 Community/www.ghaniyyu100.com 21. Alms 100 22. Yayasan Solusi Indonesia Sejahtera/ 2billion.com 23. Automatic Profit Landing/profitlanding.com 24. PT Berkah Silika Jaya (Silika Jaya/BSJ) 25. Indonesian Independent Social Association / Play 100 Club 26. Midjobs/ Midjobs Indonesia 27. Netizen Charity/netizenchar.com 28. PT Sasuka Online Indonesia/Sasuka Online/ sasuka.online 29. PT Inovatif Sinergi Indonesia (Affiliate Junction Indonesia)/Affiliatejunctionindonesia.id 30. Nge JOB/ ngejob.com 31 . Autogajian/Real Sultan (Indonesian Urun Berkah Foundation) 32. King Points (PT Forkom Digital Indonesia).

\section{RESEARCH METHOD}

This research uses post-positivism paradigm. The post-positivism paradigm wants to prove that everything is based on reality that can be built based on experience, observation, researchers are neutral towards the object of research, even though the researcher holding this paradigm remains neutral towards the object of research, he wants to examine what actually happened from the things that happened as if it was certain. Data analysis in this study used the Multiple Linear Regression Method. Hypothesis testing using partial testing ( $\mathrm{t}$ test), simultaneous ( $F$ test) and the Coefficient of Determination Test $\left(\mathrm{R}^{2}\right)$. Classical Assumption Test with Normality, Multicollinearity, Heteroscedasticity and Autocorrelation. The data used in this study are data on Foreign Debt (Government, Central and Private Banks), Foreign Investment, Debt Service Ratio, and Domestic Savings Rate 2001 - 2011. The results show that all independent variables, namely External Debt Country, Foreign Investment, Debt Service Ratio and Domestic Savings have a significant influence on Indonesia's economic growth which is represented by the GDP variable. The foreign debt and domestic savings variables have a significant positive effect on GDP, while the foreign investment and debt service ratio variables have a significant negative effect on GDP.

The discrepancy in the implementation of the omnibus law in Indonesia, between what ideally happens and what actually happens. When omnibus law is expected to be a powerful solution in dealing with regulatory chaos in Indonesia, in reality, it has transformed into a new field of problems that has spawned many negative responses from various circles of society, legal practitioners, politicians and academics. The omnibus law, which was interpreted by the Government and the DPR as the hope of a progressive breakthrough to overcome multisectoral problems, was interpreted differently by some circles of society and academics as a law that experienced juridical problems, both in terms of formal and material. Although the existence of omnibus law is not a new

\footnotetext{
1 Fika Nurul Ulya, 'Dari Alimama hingga King Poin, Ini Daftar Terbaru 32 Investasi Bodong', Kompas.com, 2020, https://money.kompas.com/read/2020/09/25/220000826/dari-alimama-hingga-king-poin-ini-daftar-terbaru-32-investasi-bodong?page=all
} 
thing in legal theory, its existence still sounds foreign in legal dialectics in Indonesia. For this reason, the purpose of this paper is to explore how the nature of the omnibus law and its implementation in Indonesia relates to legal issues in the perspective of criminal law crimes against foreign capital investment and domestic capital investment which have recently emerged and are handled by the Investment Alert Task Force of the Service Authority. Indonesian Finance (SWI-OJK). The Investment Coordinating Board (BKPM) believes the ratification of Law no. 11 of 2020 concerning Job Creation (UUCK) will increase labor absorption by encouraging investment and providing enormous space for strengthening Micro, Small and Medium Enterprises (MSMEs). The Job Creation Law, which consists of 186 articles, was ratified and signed by President Joko Widodo on November 2, 2020. The Job Creation Act, which summarizes 77 laws, is divided into 11 clusters, including the ease of doing business and improving the investment ecosystem and business activities.

A. Ease of Business The Investment Coordinating Board (BKPM) believes the ratification of Law no. 11 of 2020 concerning Job Creation (UUCK) will increase labor absorption by encouraging investment and providing enormous space for strengthening Micro, Small and Medium Enterprises (MSMEs). The Job Creation Law, which consists of 186 articles, was ratified and signed by President Joko Widodo on November 2, 2020. The Job Creation Act, which summarizes 77 laws, is divided into 11 clusters, including the ease of doing business and improving the investment ecosystem and business activities. BKPM noted that the realization of investment for the January-September 2020 period was IDR 611.6 trillion, which has reached $74.8 \%$ of the 2020 target, which is IDR 817.2 trillion. With this achievement, the realization of investment has created jobs for 861,581 Indonesian Migrant Workers (TKI) out of a total of 102,276 investment projects. In the midst of the current COVID-19 pandemic, the global economy, without exception, has contracted to a recession. This condition has an impact on increasing the unemployment rate in Indonesia. The current number of workers is around 7 million, from Aceh to Papua who are looking for jobs. Meanwhile, the labor force per year is around 2.9 million. Not to mention the condition of the COVID-19 pandemic which has an impact on workers. Data from the Ministry of Manpower of the Republic of Indonesia shows that 3.5 million workers have been laid off. With such data, the total employment opportunities that need to be prepared by the government are around 15 million. Head of BKPM Bahlil Lahadalia said that one of the steps taken by the Indonesian government to address the growth in the number of workers was to attract as many investors as possible into Indonesia. "The more investment that comes in, the greater the job opportunities that are open to the community," said Bahlil. Through Law no. 11 of 2020 concerning Job Creation (UU CK), the government is here to encourage investment through ease of business licensing for investors. So far, the issue of overlapping business licensing between the Central and Regional authorities and Ministries/Institutions $(\mathrm{K} / \mathrm{L})$ has made the licensing process difficult for investors. Not only does it take a long time, but potential investors also have to go through a protracted process. "Entrepreneurs need certainty, speed, convenience, and transparency. This need will be met with the CK Law, which will be followed up by making NSPK (Norms, Standards, Procedures, and Criteria) in order to facilitate business licensing," explained the former Chairperson of HIPMI. In addition, the government has implemented an Online Single Submission (OSS) system which is managed by the Central One Stop Service (PTSP) at BKPM. Through this OSS system, all permits will be integrated, so that there will be no overlap between the center and the regions. "With the OSS system, it is also expected to reduce Indonesia's ICOR (Incremental Capital Output Ratio) which will lead to an increase in our economic competitiveness," added Bahlil. Currently, Indonesia's ICOR is at level 6.8. The existence of UUCK is expected to reduce ICOR to a level below 4.

B. Strengthening Micro, Small and Medium Enterprises Data from the head of the Investment Coordinating Board, Bahlil, confirms that UUCK will provide enormous space for MSMEs. To date, MSMEs have contributed about $60 \%$ to Indonesia's economic growth. With 64.2 million business units or $99.7 \%$ of the total business units, MSMEs have provided employment opportunities for 120 million of the total 133 million workforce. Unfortunately, most of these MSMEs are still in the informal sector. Because of the complexity of the licensing procedure and the high cost of setting up MSMEs. With UUCK, MSME actors will be given convenience, starting from the licensing of their establishment. Thus, MSMEs will be in the formal sector so that they can get access to bank credit. Furthermore, BKPM has committed to requiring every incoming investment to cooperate with local entrepreneurs and MSMEs in investment locations. So that the inflow of investment can be directly benefited by the local community. MSME actors have the opportunity to partner with large companies, both at home and abroad. However, Bahlil underlined that this large company should not take over the shares of MSMEs. "In article 77 of the UUCK, it has been regulated that large companies may not take MSME shares. Instead, they are required to partner with MSMEs or national entrepreneurs in the regions," said Bahlil. Thus, UUCK is a law that is not only in favor of entrepreneurs/investors, but also the community, including MSME actors. No doubt, if Bahlil mentions UUCK as the law of the future, because UUCK's ability to create jobs in the future as well as 
accommodate the demographic bonus that will be experienced by Indonesia in $2035 .{ }^{1}$

\section{DISCUSSION}

Law No. 25 of 2007 concerning Investment is a mandate from the Decree of the People's Consultative Assembly of the Republic of Indonesia Number XVI/MPR/1998 concerning Economic Politics in the context of Economic Democracy, investment policy should always underlie a people's economy which involves the development of micro, small, and medium enterprises. medium, and cooperative. Law 25 of 2007 concerning Investment replaces Law Number 1 of 1967 concerning Foreign Investment as amended by Law Number 11 of 1970 concerning Amendments and Supplements to Law Number 1 of 1967 concerning Foreign Investment and Law Number 6 of 1968 concerning Domestic Investment as amended by Law Number 12 of 1970 concerning Amendments and Supplements to Law Number 6 of 1968 concerning Domestic Investment needs to be replaced because it is no longer in accordance with the needs of accelerating economic development and national legal development, particularly in the investment sector. The main objective of Law 25 of 2007 concerning Investment is to create a just and prosperous society based on Pancasila and the 1945 Constitution of the Republic of Indonesia. As well as to accelerate national economic development and realize Indonesia's political and economic sovereignty, it is necessary to increase investment to process economic potential into real economic strength by using capital originating both from within the country and from abroad.

The results of the report from the Investment Alert Task Force team of the Financial Services Authority of the Republic of Indonesia revealed illegal investments. Of the 99 entities, 87 Illegal Futures or Forex Trading, 2 Illegal Direct Selling, 3 Illegal Cryptocurrency Investments, 3 Money Investments, and 4 others. The public needs to be careful of this illegal investment if there is an attractive legal and logical offer. Ask for the license of legal entities and their activities and see the rationality of the returns (Head of the Investment Alert Task Force Togam L Tobing, Friday (3/7/2020) $)^{2}$. The jublah shows that the crime rate in the field of foreign and national investment is quite high and endangers the people's economy. Investment fraud with various modes and social media entities is increasing and endangering the public economic actors. A total of 35 global investors with an asset under management (AUM) value of US\$4.1 trillion wrote an open letter to President Joko Widodo regarding the Job Creation Act. The regulation, which was made using the omnibus law method, was just passed by the parliament (5/10/2020). In the open letter, it is explained that the Job Creation Act risks damaging environmental, social and government conditions. These global investors are concerned that changes in the licensing framework, various environmental management requirements and public consultations and the sanctions system will have a negative impact on the environment, human rights, and employment. The Ministry of Finance considers that the Job Creation Law is a Capital for Economic Recovery in 2021. This is considered to cause significant uncertainty and can affect the attractiveness of the Indonesian market. While we recognize the need for reform of business law in Indonesia, we have concerns about the negative impact of certain environmental protection measures that are affected by the Omnibus Law on Job Creation. We have concerns about the negative impact of environmental protection measures that are affected by the Omnibus Law of the Job Creation Act. Peter van der Werf, from Robeco, is protesting against copyright laws. Previously, Reuters reported that 35 investors who wrote open letters included Aviva Investor, Legal \& General Investment Management, Church of England Pensions Board, Robevo, and Sumitomo Mitsui Trust Assets Management. It is feared that the Omnibus Law on the Job Creation Law could hinder efforts to protect Indonesia's forests. The long-term impact, the world will find it increasingly difficult to prevent the extinction of biodiversity and slow down climate change which is now a problem with the people of the Earth. Although the law was passed to increase foreign investment in Indonesia, this law is considered to have a risk of conflicting with international standards of practice which aims to prevent unwanted harm from business activities.

The Job Creation Law Encourages Indonesia to Become a Developed Country Previously, the Coordinating Minister for Economic Affairs Ailrnagga Hartarto stated that the Job Creation Act is one way for Indonesia to escape the middle-income trap. President Joko Widodo's ambition was previously expressed when Jokowi delivered his state speech in October 2019. Jokowi proposes, This is a long journey The issuance of the Job Creation Law, Joko Widodo in the inauguration of the elected president for the 2019-2024 period on October 20, 2019 and has shown that we have the potential to get out of the middle-income trap. Airlangga when delivering a speech after the ratification of the Job Creation Law at the DPR RI Plenary Meeting. To achieve this ambition, Airlangga said, the government must be able to provide jobs and improve the quality of the workforce. On the other hand, it is necessary to cut domestic regulations or regulations so that the domestic investment climate is attractive. For this reason, a job creation law was introduced which changed or revised several barriers with the aim of creating job opportunities. The law is an instrument for simplification and improvement of bureaucratic

\footnotetext{
${ }^{1}$ BPKM, 'UU Cipta Kerja : Dorong Investasi, Ciptakan Lapangan Kerja', 2020, https://www.bkpm.go.id/id/publikasi/detail/berita/uu-ciptakerja-dorong-investasi-ciptakan-lapangan-kerja 1

2 Rahajeng Kusumo Hastuti, 'OJK Kembali Temukan 99 Investasi Bodong, Nih Daftarnya!', 2020, https://www.cnbcindonesia.com/tech/20200703133332-37-170000/ojk-kembali-temukan-99-investasi-bodong-nih-daftarnya
} 
activity. The Job Creation Act consists of 11 clusters. These include Simplification of Licensing, Investment Requirements, Employment, Ease of Doing Business, Empowerment and Protection of MSMEs, Research and Innovation Support, Government Administration, Imposition of Sanctions, Land Acquisition, Ease of Investment and Government Projects, and Economic Zones. provisions contained in the Omnibus Law on Job Creation (Ciptaker). In the regulation, the government deliberately changed a number of provisions related to investment in order to attract capital flows into the country. Furthermore, the capital will be used to absorb Indonesian workers. New regulations in part changes in Law No. 25 of 2007 concerning Investment. Part Five Simplification of Investment Requirements in Certain Sectors Paragraph 1, General Article 76 In order to facilitate the public, especially Business Actors, in investing in certain sectors, namely investment, banking, and sharia banking, this Job Creation Law changes, deletes, or stipulates new arrangements for several provisions, which is set in:

a. Law Number 25 Year 2007 concerning Investment (State Gazette of the Republic of Indonesia Year 2007 Number 67, Supplement to State Gazette of the Republic of Indonesia Number a72fl; b. Law Number 7 of 1992 concerning Banking (State Gazette of the Republic of Indonesia of 1992 Number 31, Supplement to the State Gazette of the Republic of Indonesia Number 34721 as amended by Law Number 10 of 1998 concerning Amendments to Law Number 7 of L992 concerning Banking ( State Gazette of the Republic of Indonesia of 1998 Number 182, Supplement to the State Gazette of the Republic of Indonesia Number 3790); and c. Law Number 21 of 2008 concerning Sharia Banking (State Gazette of the Republic of Indonesia of 2008 Number 94, Supplement to the State Gazette of the Republic of Indonesia Number 4867). Paragraph 2, Investment Article 77 Several provisions in Law Number 25 Year 2007 concerning Investment (State Gazette of the Republic of Indonesia Year 2007 Number 67, Supplement to State Gazette of the Republic of Indonesia Number 47241 amended as follows: 1. Provisions . SK No. 052028 A 2 president of the republic of Indonesia $-528-1$ The provisions of Article 2 are amended to read as follows: Article 2 The provisions of this Law shall apply and become the main reference for investment in all sectors within the territory of the Unitary State of the Republic of Indonesia. The provisions of Article 12 are amended to read as follows : Article 12 (1) All business fields are open for investment activities, except for business fields which are declared closed for investment or activities which can only be carried out by the Central Government Article 21 Business fields closed for investment as referred to in paragraph (1) includes: a. cultivation and industry of narcotics class I; b. all forms of gambling and $\mathrm{n}$ /or casino; c. catching fish species listed in d. utilization or extraction of corals and utilization or extraction of corals from nature which are used for building materials of calcium lime, aquariums, and souvenirs/jewelry, as well as live or recent death corals from nature; e. chemical weapons manufacturing industry; and f. industrial chemical industry and industrial ozone depleting materials.

SK No. 052029 A (3) provisions of the President of the republic of Indonesia -529 - (3). Further provisions regarding the capital investment requirements as referred to in paragraphs (1) and (2) shall be regulated in a Presidential Regulation. 3 The provisions of Article 13 are amended to read as follows: Article 13 (1) The Central Government or Regional Governments in accordance with their respective authorities provide convenience, empowerment, and protection for cooperatives and micro, small, and medium-sized enterprises in the implementation of investment based on norms, standards, procedures, and the criteria set by the Central Government. (2) The protection and empowerment as referred to in paragraph (1) is in the form of fostering and developing cooperatives and micro, small and medium enterprises through: a. partnership program; b. human resource training; c. increasing competitiveness; d. providing incentives for innovation and market expansion; e. access to financing; and $\mathrm{f}$. wide dissemination of information. (3) The protection and empowerment as referred to in paragraph (21 shall be carried out by the Central Government and/or Regional Government in accordance with their respective authorities based on the norms, standards, procedures, and criteria established by the Central Government. (41 Partnership as referred to in paragraph (21 letter a) is a partnership as referred to in the law in the field of micro, small and medium enterprises SK No. 052030A 4. Provisions 4 presidents of the republic of indonesia -530- The provisions of the following article: 18 are amended to read as Article 18 (1) The Central Government provides facilities to investors capital that makes investment (2) Investment facilities as referred to in paragraph (1) may be granted to investors who: a. conduct business expansion; or b. make new investments. (3) Investments that receive the facilities as referred to in paragraph (21 at least meets the following criteria: a. absorbs a lot of manpower; b. includes a high priority scale; c. includes infrastructure development; $d$. perform technology transfer; e. carry out pioneer industry; f. are in remote areas, underdeveloped areas, border areas, or other areas deemed necessary; g. maintain environmental sustainability; h. carry out research, development, and innovation activities; i. partner with micro, small, medium enterprises or cooperatives; $j$. industries that use domestically produced capital goods or machinery or equipment; and/or k. including tourism business development. (4) The form of facilities provided to investment as referred to in paragraphs (2) and (3) is carried out in accordance with the provisions of the legislation in the field of taxation. SK No. 052031 A 5. Provisions of the president of the republic of Indonesia - 531 -5 The provisions of Article 25 are amended to read as follows: Article 25 (1) Investors who make investments in Indonesia must be carried out in accordance with 
the provisions referred to in Article 5. (2) Ratification of the establishment of a domestic investment business entity in the form of a legal entity or not a legal entity is carried out in accordance with the provisions of the laws and regulations. (3) The legalization of the establishment of a foreign investment business entity in the form of a limited liability company is carried out in accordance with the provisions of the legislation. (41 An investment company that will carry out business activities is required to fulfill a Business Licensing from the Central Government or Regional Government in accordance with their authority based on the norms, standards, procedures, and criteria set by the Central Government. This means that Law No. 25 of 2007 concerning Investors can still used as a source of law, when the Omnibus law Law No. 11 of 2020 concerning Job Creation does not remove other provisions, including legal sanctions in the investment law that are not changed in the omnibus law of Job Creation No. 11 of 2020. The following are the regulations for the dispute resolution process and sanctions against parties who violate foreign and domestic investments according to the provisions of Law No. 25 of 2007 concerning Investment.

Article 32 1. In the event of a dispute in the investment sector between the Government and the investor, the parties shall first resolve the dispute through deliberation and consensus. 2. In the event that the dispute resolution as referred to in paragraph (1) is not reached, the dispute resolution may be carried out through arbitration or alternative dispute resolution or courts in accordance with the provisions of the legislation. 3. In the event of a dispute in the investment sector between the Government and a domestic investor, the parties may resolve the dispute through arbitration based on the agreement of the parties, and if the dispute resolution through arbitration is not agreed, the dispute resolution will be carried out in court. 4 . In the event of a dispute in the investment sector between the Government and a foreign investor, the parties will resolve the dispute through international arbitration which must be agreed upon by the parties. Article 331 . Domestic investors and foreign investors who invest in the form of a limited liability company are prohibited from entering into agreements and/or statements confirming that the ownership of shares in a limited liability company is for and on behalf of another person. 2. In the event that domestic investors and foreign investors make an agreement and/or statement as referred to in paragraph (1), the agreement and/or statement is declared null and void. 3 . In the event that an investor who carries out business activities based on a cooperation agreement or contract with the Government commits a corporate crime in the form of a tax crime, inflated recovery costs, and other forms of inflated costs to minimize profits that result in state losses based on findings or examinations by the authorized official. authorized and has received a court decision with permanent legal force, the Government terminates the agreement or cooperation contract with the investor concerned. Article 341 . The business entity or individual business as referred to in Article 5 which does not fulfill the obligations as stipulated in Article 15 may be subject to administrative sanctions in the form of: a. written warning; b. limitation of business activities; c. freezing of business activities and/or investment facilities; or $\mathrm{d}$. revocation of business activities and/or investment facilities. 2. The administrative sanctions as referred to in paragraph (1) shall be imposed by the authorized agency or institution in accordance with the provisions of the legislation. 3 . In addition to being subject to administrative sanctions, business entities or individual businesses may be subject to other sanctions in accordance with the provisions of laws and regulations Article 35 International agreements, whether bilateral, regional, or multilateral, in the field of investment that have been approved by the Government of Indonesia before this Law comes into force, remain in force until the end of the agreement. Article 36 Draft international agreements, whether bilateral, regional, or multilateral, in the field of investment that have not been approved by the Government of Indonesia at the time this Law comes into effect must be adjusted to the provisions of this Law.

\section{CONCLUSION}

In the conclusion of writing this journal, the author of the consideration of Law 25 of 2007 concerning Investment is that in order to realize a just and prosperous society based on Pancasila and the 1945 Constitution of the Republic of Indonesia, it is necessary to carry out sustainable national economic development based on economic democracy to achieve the goal. patriotic; that in accordance with the mandate contained in the Decree of the People's Consultative Assembly of the Republic of Indonesia Number XVI/MPR/1998 concerning Economic Politics in the context of Economic Democracy, investment policy should always underlie a people's economy which involves the development of micro, small, medium enterprises, and cooperatives; that in order to accelerate national economic development and realize Indonesia's political and economic sovereignty, it is necessary to increase investment to process economic potential into real economic strength by using capital originating from within the country as well as from abroad; that in the face of changes in the global economy and Indonesia's participation in various international cooperations, it is necessary to create a conducive, promotive, investment climate that provides legal certainty, justice and efficiency while still taking into account the interests of the national economy; that Law Number 1 of 1967 concerning Foreign Investment as amended by Law Number 11 of 1970 concerning Amendments and Supplements to Law Number 1 of 1967 concerning Foreign Investment and Law Number 6 of 1968 concerning Investment in The country as amended by Law Number 12 
of 1970 concerning Amendments and Supplements to Law Number 6 of 1968 concerning Domestic Investment needs to be replaced because it is no longer in accordance with the needs of accelerating economic development and development of national law, especially in the field of investment; that based on the considerations as referred to in letter $\mathrm{a}$, letter $\mathrm{b}$, letter $\mathrm{c}$, letter $\mathrm{d}$, and letter e, it is necessary to enact a Law on Investment. Job creation is an effort to create jobs through facilitating, protecting, and empowering cooperatives and micro, small and medium enterprises, improving the investment ecosystem and facilitating business, and investing in the Central Government and accelerating national strategic projects. The discrepancy in the implementation of the omnibus law in Indonesia, between what ideally happens and what actually happens. When omnibus law is expected to be a powerful solution in dealing with regulatory chaos in Indonesia, in reality, it has transformed into a new field of problems that has spawned many negative responses from various circles of society, legal practitioners, politicians and academics. The omnibus law, which was interpreted by the Government and the DPR as the hope of a progressive breakthrough to overcome multi-sectoral problems, was interpreted differently by some circles of society and academics as a law that experienced juridical problems, both in terms of formal and material. Although the existence of omnibus law is not a new thing in legal theory, its existence still sounds foreign in legal dialectics in Indonesia.

\section{REFFERENCES \\ Book}

R. Sugandhi, Criminal Code With Explanation, National Business, Surabaya, 1980- pp. 390-396

\section{Journal}

Barda Nafawi Arief, Scientific Approaches and Religious Approaches in the Context of Optimizing and Reforming Criminal Law Enforcement in Indonesia, Publishing Agency Diponegoro University, Semarang, 2012-page ;

\section{Regulations}

Decree of the People's Consultative Assembly of the Republic of Indonesia Number XVI of 1998 concerning Economic Politics in the Context of Economic Democracy as a source of material law.

Law no. 11 of 2020 concerning Job Creation (UUCK)

Law Number 25 of 2007 concerning Investment

\section{Internet}

Muti Fauzia, (2020), 35 Investor Asing Nyatakan Keresahannya terhadap Pengesahan UU Cipta Kerja, Kompas.com, https://money.kompas.com/read/2020/10/06/164906226/35-investor-asing-takan-keresahanterhadap-pengesahan-uu-cipta-karya?page=all.

Joglo abang, https://www.jogloabang.com/library/uu-25-2007-penanaman-modal

Ferry Sandi, (2021) Jangan Salah Masuk, 11 Investasi Bodong Diblok OJK, CNBC Indonesia, https://www.cnbcindonesia.com/market/20210724070700-17-263246/jangan-salah-masuk-11-investasibodong-diblok-ojk

Rahajeng Kusumo Hastuti, (2020) OJK Kembali Temukan 99 Investasi Bodong, Nih Daftarnya!, CNBC Indonesia, https://www.cnbcindonesia.com/tech/20200703133332-37-170000/ojk-kembali-temukan-99investasi-bodong-nih-daftarnya

Fika Nurul Ulya, (2020), Dari Alimama hingga King Poin, Ini Daftar Terbaru 32 Investasi Bodong, Kompas.com. https://money.kompas.com/read/2020/09/25/220000826/dari-alimama-hingga-king-poin-inidaftar-terbaru-32-investasi-bodong?page=all

BPKM, (2020), UU Cipta Kerja : Dorong Investasi, Ciptakan Lapangan Kerja, https://www.bkpm.go.id/id/publikasi/detail/berita/uu-cipta-kerja-dorong-investasi-ciptakan-lapangan-kerja 1. 